\title{
A HUMAN LIPOPROTEIN POLYMORPHISM
}

\author{
By BARUCH S. BLUMBERG, DAVID BERNANKE, AND ANTHONY C. ALLISON \\ (From the Geographic Medicine and Genetics Section, National Institutes of Health, Bethesda, \\ Md., and the National Institute for Medical Research, London, England)
}

(Submitted for publication March 8, 1962; accepted July 3, 1962)

During the past decade, several groups of inherited human serum proteins constituting polymorphic systems have been discovered. These include the haptoglobins, transferrins, gamma globulin groups, and the group-specific substances (for review see Reference 1 ). In some of these systems the gene frequencies are such that a patient receiving repeated blood transfusions would have a high probability of receiving serum from an individual of a phenotype different from his own. For example, in a single transfusion, a European of haptoglobin type 1-1 (approximately 15 per cent of a European population) would have a chance of about 1 in 3 of receiving a serum of haptoglobin type 2-2 and a chance of about 1 in 2 of receiving type 2-1. Consideration of some of the other serum systems leads to the same general conclusion: a frequently transfused individual would almost certainly receive transfused plasma containing some proteins slightly different from his own. There is no evidence that any of the known differences among these proteins leads to antibody formation $(2,3)$. Nonetheless, under some circumstances and in some individuals either the known protein polymorphisms or other still undiscovered polymorphisms may induce isoimmunization. This has been considered possible for some time, and analogous findings are known in animals (4-6).

In a study of human material, Allison and Blumberg (7) collected sera of patients who had required multiple transfusions for a variety of reasons and examined them for precipitating antibodies against normal human sera. With the Ouchterlony technique, a substance which acted as a precipitating antibody was found in the serum of a patient, C. de B., who had received approximately 50 transfusions because of a refractory anemia of unknown cause. The precipitin line was formed between the serum of C. de B. and some, but not all, normal sera (Figure 1). The antibody-like material in the serum of the transfused patient appeared to be 7S gamma globulin (7) and the "antigen" with which it reacted was a low-density beta-lipoprotein (8). Sera of 55 per cent of a U.S. population formed precipitin lines with this serum (see below), suggesting that the reacting "antigen" might be inherited. Preliminary population and family studies were consistent with the hypothesis that individuals homozygous for a recessive autosomal allele, termed $A g$, were non-reactors, of phenotype $\mathrm{Ag}(\mathrm{a}-)$. Those homozygous or heterozygous for its dominant allele $A g^{4}$, those of phenotype $\mathrm{Ag}(\mathrm{a}+)$, did react $(7,9)$.

Additional studies are presented on the system determined by the $\mathrm{C}$. de $\mathrm{B}$. serum, the $\mathrm{Ag}$ (a) system, and further evidence for the genetic hypothesis is advanced. Other sera containing precipitins from transfused individuals have been found, and some of their properties will be described.

\section{MATERIAL AND METHODS}

Ouchterlony procedure. The precipitin reaction was carried out in agar gel as previously described (7). In testing the sera of transfused patients with a panel of normal sera, each transfused patient's serum was placed in the center well, and a different panel serum in each of the six peripheral wells.

Post-transfusion sera. The blood of 109 frequently transfused patients was obtained by venipuncture. Each serum was removed from the clotted blood on the day of venipuncture and stored at $-20^{\circ} \mathrm{C}$ until tested. In some cases, plasma separated from acid citrate dextrosetreated blood was used. Specimens were collected at the following institutions: Clinical Center of the National Institutes of Health, Bethesda; New York HospitalCornell Medical Center, Frances Delafield Hospital, and Presbyterian Hospital, New York City; Children's Hospital Medical Center, Boston; and Mt. Alto Veterans' Administration Hospital, Washington, D. C. The diagnoses of these 109 patients are listed in Table I. All of these patients had received 5 or more transfusions, and 33 had received approximately 40 or more.

Panel sera. Each transfused serum was tested against a panel of 24 sera obtained from non-hospitalized, ap- 
TABLE I

Discase categories of transfused patients

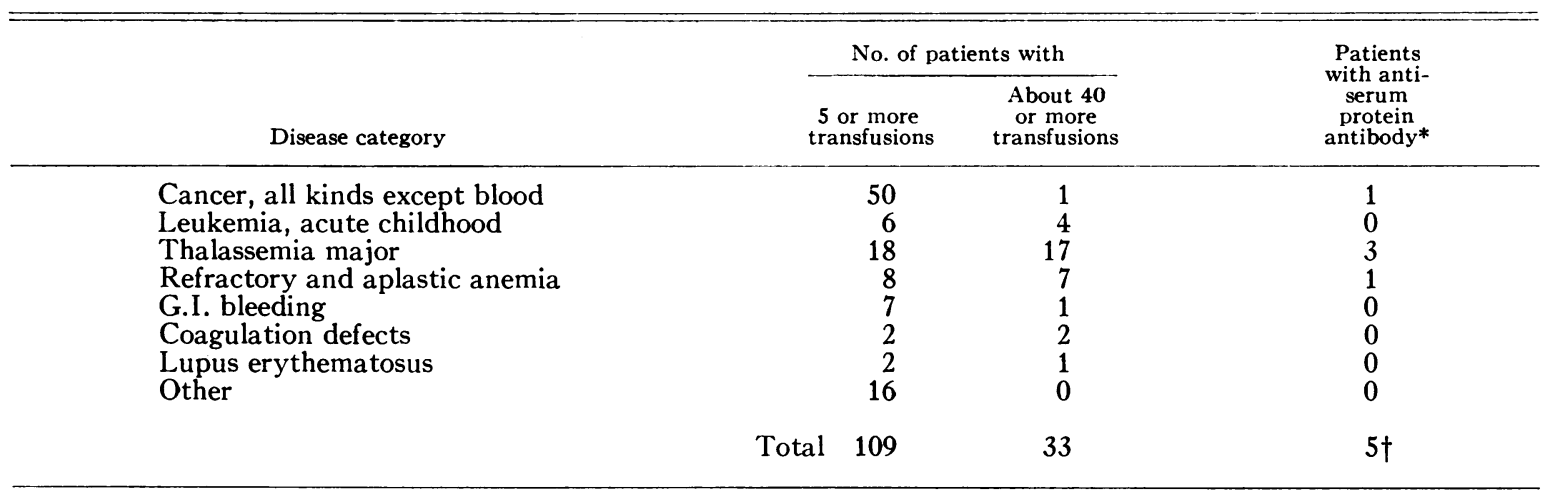

* Detectable by the Ouchterlony method.

$\dagger$ All with about 40 or more transfusions.

parently normal individuals, including males, females, children, and adults (Table II). The sera were from U. S. whites (7), Negroes, Indians (10), Eskimos (10), Vietnamese (11), Micronesians (12), and Polynesians (11). The samples for the population studies were selected casually from sera collected for population studies of other inherited traits $(7,10-12)$. The U. S. white sample was composed of presumably healthy employees of the National Institutes of Health and members of U. S. white families described elsewhere (7). The U. S. Negro sample was obtained during a population study in Evans and Bulloch counties, Georgia. ${ }^{1}$ Methods of collection of the remaining sera are given in the references for the other populations; those of family and twin sera will be described in the next section.

\section{RESULTS}

Studies on sera of transfused patients. To help rule out the possibility that the antibody was naturally occurring and not related to multiple transfusion, the sera of 163 apparently normal individuals who had received no transfusions were tested

TABLE II

Distribution of $\mathrm{Ag}(a)$ phenotypes in various populations

\begin{tabular}{|c|c|c|c|c|c|}
\hline \multirow[b]{2}{*}{ Population } & \multirow{2}{*}{$\begin{array}{c}\text { Total } \\
\text { no. }\end{array}$} & \multicolumn{2}{|c|}{$A g(a+)$} & \multicolumn{2}{|c|}{$\mathrm{Ag}(\mathrm{a}-)$} \\
\hline & & No. & $\%$ & No. & $\%$ \\
\hline Polynesian, Bora Bora & 96 & 96 & 100 & 0 & 0 \\
\hline Micronesian, Rongelap Atoll & 101 & 95 & 95 & 6 & 5 \\
\hline Eskimo, North Alaska & 97 & 79 & 81 & 18 & 19 \\
\hline Vietnamese & 99 & 70 & 71 & 29 & 29 \\
\hline Athabascan Indian, Alaska & 102 & 69 & 68 & 33 & 32 \\
\hline U.S. Negro & 167 & 92 & 55 & 75 & 45 \\
\hline U. S. white & 188 & 103 & 54 & 85 & 46 \\
\hline
\end{tabular}

${ }^{1}$ In preparation, by A. J. Cooper. for the presence of antibody in the same manner as the 109 sera of transfused patients. Five of the transfused patients, but none of the nontransfused had a precipitin (Table III, $\mathrm{p}<.01$ ). All the antibodies were found in the sera of patients who had received approximately 40 or more transfusions (Table IV).

Some of the family members of three of the antibody-formers were studied. The parents of $\mathrm{Ba}$., the parents and brother of P. C., and the daughter of $\mathrm{C}$. de $\mathrm{B}$. were tested and no antibody was found. The family of P. C. is particularly interesting. Both she and her brother have thalassemia, for which they have received multiple transfusions. P. C. was born November 2, 1942, and the diagnosis of Cooley's anemia made at age 4 years. She has required nearly monthly transfusions and has received about 250 transfusions. Her brother was born September 19, 1945, nearly 3 years after his sister, and the diagnosis of Cooley's anemia was made at 11 months. $\mathrm{He}$ also has been treated with monthly transfusions,

TABLE III

Comparison of antibody frequency in transfused and nontransfused subjects

\begin{tabular}{lccc}
\hline \hline & \multicolumn{3}{c}{ No. of subjects with } \\
\cline { 2 - 4 } & $\begin{array}{c}\text { No } \\
\text { trans- } \\
\text { fusions }\end{array}$ & $\begin{array}{c}5 \text { or } \\
\text { more } \\
\text { trans- } \\
\text { fusions }\end{array}$ & $\begin{array}{c}\text { Above } \\
40 \text { or } \\
\text { more } \\
\text { transfusions }\end{array}$ \\
\hline Number studied & 163 & 109 & 33 \\
Number with antibody & 0 & 5 & 5 \\
Per cent with antibody & 0 & 4.5 & 15.1 \\
& & $\mathrm{p}<.01$ & $\mathrm{p}<.001$ \\
\hline
\end{tabular}


TABLE IV

Transfused patients forming precipitins

\begin{tabular}{|c|c|c|c|c|c|c|}
\hline Patient & Age & Sex & Diagnosis & $\begin{array}{c}\text { No. of } \\
\text { transfusions }\end{array}$ & $\begin{array}{l}\text { Year of } \\
\text { first trans- } \\
\text { fusion }\end{array}$ & $\begin{array}{l}\text { Date blood } \\
\text { collected for } \\
\text { antibody study }\end{array}$ \\
\hline $\begin{array}{l}\text { C.deB. } \\
\text { P.C. } \\
\text { Br. }\end{array}$ & $\begin{array}{l}66 \\
18 \\
45\end{array}$ & $\begin{array}{l}\mathrm{M} \\
\mathrm{F} \\
\mathrm{M}\end{array}$ & $\begin{array}{l}\text { Refractory anemia } \\
\text { Cooley's anemia } \\
\text { Zollinger-Ellison } \\
\text { syndrome }\end{array}$ & $\begin{array}{l}\sim 50 \\
\sim 250 \\
\sim 40^{*}\end{array}$ & $\begin{array}{l}1957 \\
1946 \\
1956\end{array}$ & $\begin{array}{l}\text { Aug., } 1960 \\
\text { Dec., } 1960 \\
\text { Jan., } 1961\end{array}$ \\
\hline $\begin{array}{l}\text { M. } \\
\text { B. }\end{array}$ & $\begin{array}{r}6 \\
14\end{array}$ & $\begin{array}{l}\mathrm{F} \\
\mathrm{M}\end{array}$ & $\begin{array}{l}\text { Cooley's anemia } \\
\text { Cooley's anemia }\end{array}$ & $\begin{array}{l}\sim 40 \\
\sim 250\end{array}$ & $\begin{array}{l}1956 \\
1947\end{array}$ & $\begin{array}{l}\text { Dec., } 1960 \\
\text { Dec., } 1960\end{array}$ \\
\hline
\end{tabular}

* Exact number of transfusions received is not known, but is probably 40 or more.

and at the time of testing had received approximately 200. Despite the similarity in disease pattern and the nearly similar number of transfusions given at the same frequency, only P. C. has developed a detectable antibody. It is possible that her brother will develop an antibody later in life.

Repeated transfusions in antibody-formers. With the exception of Br., who died presumably as a result of his primary disease, all the antibodyformers continued to receive frequent transfusions after the discovery of antibody. In no case did they develop sufficiently severe transfusion reactions to require interruption of transfusion

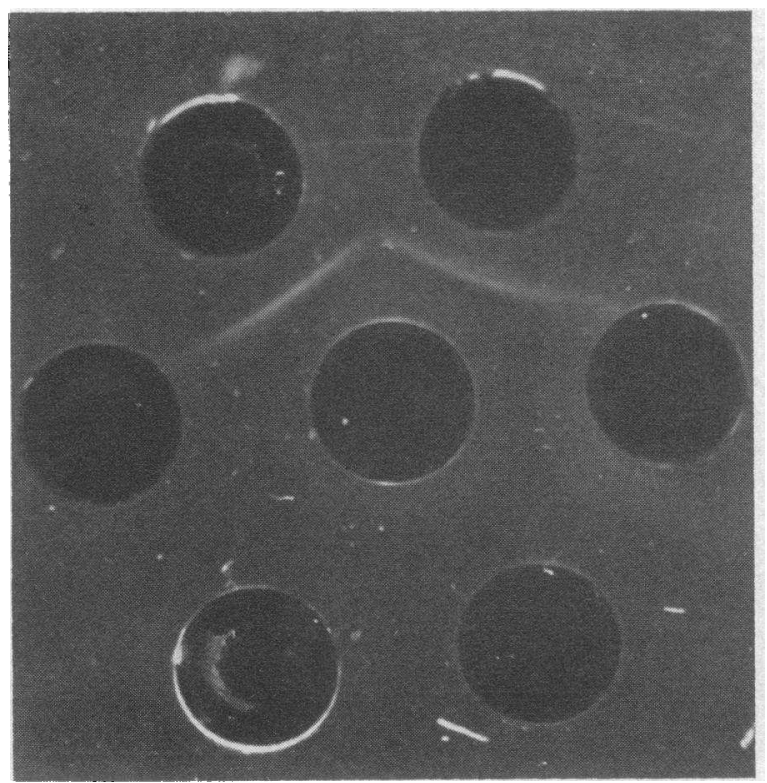

Fig. 1. Precipitin line in Ouchterlony plate FORMED BETWEEN CENTER WELL, CONTAINING SERUM OF C. DE B., ANd 2 OF 6 OUter WELls, containing SERA FROM NORMAL SUBJECTS. Note concavity of line toward the peripheral wells, suggesting an antigen of high molecular weight. therapy. C. de B., whose case has been previously described (7), was observed at the Clinical Center, National Institutes of Health, for the possibility of transfusion reactions. The patient regularly had a moderate rise in temperature every afternoon. After the administration of 2 units of $\operatorname{Ag}(\mathrm{a}-)$ blood, there was a rise slightly above the usual; a similar rise was seen when 2 units of $\mathrm{Ag}(\mathrm{a}+)$ blood was administered. Comparable results were obtained with 6 other units of blood. Figure 2 shows a typical study.

Studies on the $A g(a)$ system. The first and most clearly reacting antibody was found in the serum of patient $\mathrm{C}$. de $\mathrm{B}$. His serum defined the $\mathrm{Ag}$ (a) beta-lipoprotein system (7-9). Further studies on the $\mathrm{Ag}(\mathrm{a})$ phenotypes are presented here. With nearly all sera, the precipitin line was concave towards the antigen well and coalesced with the precipitin line of adjoining sera. Occasionally, other kinds of reaction were seen. These included instances where two separate lines were

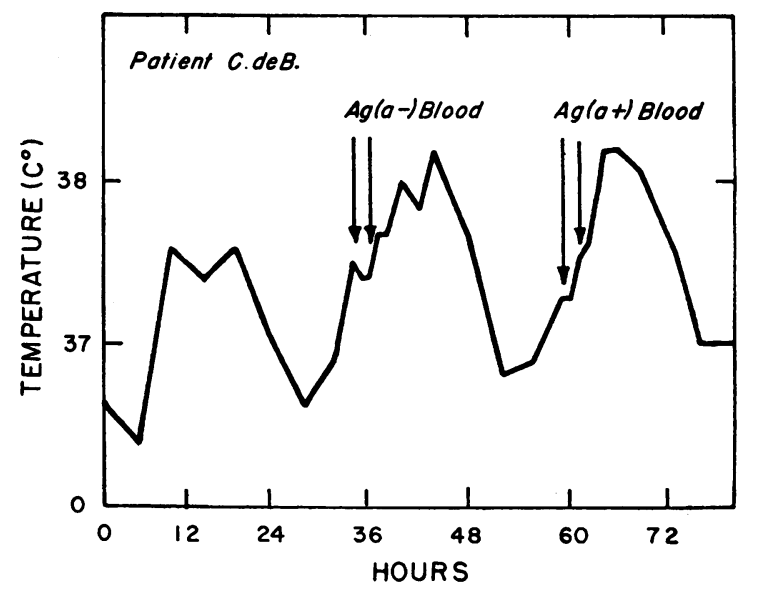

Fig. 2. Temperature chart of C. DE B. In Relation to transfusions of AG(A + ) ANd $\mathrm{Ag}(\mathrm{A}-)$ BLood. 
TABLE V

Frequency of $A g(a+)$ phenotype by sex in U.S. Negro and white populations

\begin{tabular}{|c|c|c|c|c|c|c|c|c|c|}
\hline \multirow[b]{3}{*}{ Population } & \multicolumn{3}{|c|}{ Males } & \multicolumn{3}{|c|}{ Females } & \multicolumn{3}{|c|}{ Males and females } \\
\hline & \multirow{2}{*}{$\begin{array}{c}\text { Total } \\
\text { no. }\end{array}$} & \multicolumn{2}{|c|}{$\operatorname{Ag}(a+)$} & \multirow{2}{*}{$\begin{array}{c}\text { Total } \\
\text { no. }\end{array}$} & \multicolumn{2}{|c|}{$\mathrm{Ag}(\mathrm{a}+)$} & \multirow{2}{*}{$\begin{array}{c}\text { Total } \\
\text { no. }\end{array}$} & \multicolumn{2}{|c|}{$\mathrm{Ag}(\mathrm{a}+)$} \\
\hline & & No. & $\%$ & & No. & $\%$ & & No. & $\%$ \\
\hline $\begin{array}{l}\text { U. S. Negro } \\
\text { U. S. white }\end{array}$ & $\begin{array}{l}69 \\
85\end{array}$ & $\begin{array}{l}38 \\
41\end{array}$ & $\begin{array}{l}55 \\
48\end{array}$ & $\begin{array}{r}98 \\
103\end{array}$ & $\begin{array}{l}54 \\
62\end{array}$ & $\begin{array}{l}55 \\
61\end{array}$ & $\begin{array}{l}167 \\
188\end{array}$ & $\begin{array}{r}92 \\
103\end{array}$ & $\begin{array}{l}55 \\
54\end{array}$ \\
\hline Total U. S. & 154 & 79 & 51 & 201 & 116 & 58 & 355 & 195 & 55 \\
\hline
\end{tabular}

seen and also where the single precipitin line was qualitatively different from the usual line.

Sex and age. There was no significant sex difference in the frequency of positive reactors, those of $\mathrm{Ag}(\mathrm{a}+)$ phenotype, in U. S. white and Negro populations (Table V). The distribution of positive reactors by age in 356 Americans (168 U.S. Negroes, 188 U. S. white) is shown in Table VI). Although there appears to be little age nonhomogeneity, the sample is not large enough to rule out small differences. Testing a larger number of people older than 60 might show whether the observed slight drop in the frequency of $\mathrm{Ag}(\mathrm{a}+)$ in this group is significant.

Twin studies. The twin sera were presented to us by Dr. J. McDonough of the Public Health Service Heart Disease Control Program, and were collected in Evans and Bulloch counties in southern Georgia (13). A census of the area was taken and the total number of twin pairs ascertained. Whenever both twins were still resident locally, they were asked to participate in the study. All those volunteering were examined and blood

TABLE VI

Frequency of $\mathrm{Ag}(\mathrm{a}+)$ phenotype in combined $U$. S. white and Negro population by age group

\begin{tabular}{|c|c|c|c|}
\hline \multirow[b]{2}{*}{ Age group } & \multirow[b]{2}{*}{ Total } & \multicolumn{2}{|c|}{ No. $\mathbf{A g}(a+)$} \\
\hline & & Expected * & Observed \\
\hline years & & & \\
\hline $\begin{array}{l}0 \text { to } 9 \\
10 \text { to } 19 \\
20 \text { to } 29 \\
30 \text { to } 39 \\
40 \text { to } 49 \\
50 \text { to } 59 \\
60+\end{array}$ & $\begin{array}{l}28 \\
79 \\
52 \\
56 \\
87 \\
31 \\
23\end{array}$ & $\begin{array}{l}15.4 \\
43.5 \\
28.6 \\
30.8 \\
47.9 \\
17.1 \\
12.7\end{array}$ & $\begin{array}{l}16 \\
40 \\
25 \\
36 \\
50 \\
18 \\
10\end{array}$ \\
\hline Total & $\begin{array}{c}356 \\
0.8\end{array}$ & & 195 \\
\hline
\end{tabular}

* Calculated by multiplying total number of group by 0.55 , (the fraction of the entire population that is $\operatorname{Ag}(\mathrm{a}+)$. samples obtained; 56 pairs of twins were located, 23 monozygotic, 27 dizygotic, and 6 undetermined. Blood specimens from a total of 18 identical and 27 nonidentical twin pairs were available for the present study. The diagnosis of zygosity was made with the following criteria : sex; gross physical appearance; A-B-O, $\mathrm{Rh}_{0}, \mathrm{rh}^{\prime}$, and $\mathrm{rh}^{\prime \prime}$ red blood cell groups; and haptoglobin serum types. For 4 identical and 4 nonidentical pairs, the following blood group data were also obtained: $\mathrm{M}-\mathrm{N}-\mathrm{S}, \mathrm{Fy}, \mathrm{Jk}, \mathrm{C}^{\mathrm{w}}, \mathrm{P}, \mathrm{Le}, \mathrm{Lu}$, Diego, and Js.

Of the 18 supposed identical twin pairs, 17 were concordant and one discordant for the $\mathrm{Ag}(\mathrm{a})$ phenotype (Table VII). Of the 27 nonidentical twin pairs, 17 were concordant and 10 discordant. The difference in concordance between the identical and nonidentical twin pairs is highly significant.

Both members of the discordant, presumably identical twin pair, were white males of blood group $\mathrm{O} R \mathrm{Rh}_{0} \mathrm{Rh}^{1}$ and haptoglobin type 2-2. Smith and Penrose (14) have provided a method for calculating the probability of zygosity from blood groups and other traits. From the bloodgroup frequencies in their tables and a frequency of 0.387 for the haptoglobin type one $\left(H p^{1}\right)$ gene, it was calculated that the chances of dizygosity in this pair are approximately 3 in 10 . It is diffcult to explain the existence of a discordant pair among the presumably identical twins, but there are several possible explanations: the twins may not have been identical; the phenotype may have been misclassified; or there may be a nongenetic factor affecting the phenotype.

Family studies. Preliminary family studies of the $\mathrm{Ag}$ (a) phenotype in $29 \mathrm{U}$. S. and 8 Micronesian families have been presented previously (7). The results supported the hypothesis that individuals homozygous for the recessive gene $A g$ did not react with the C. de B. antibody. Those homozygous or heterozygous for its dominant al- 
TABLE VII

Twin studies of $\mathrm{Ag}(\mathrm{a}+)$ phenotype

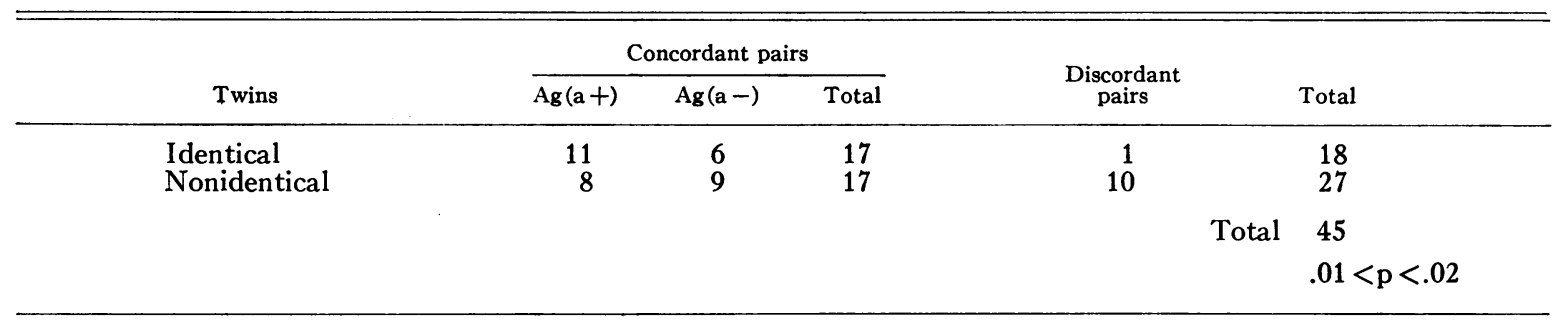

lele $A g^{\mathbf{A}}$ did react. According to this hypothesis, the offspring of $\mathrm{Ag}(\mathrm{a}+)$ and $\mathrm{Ag}(\mathrm{a}+)$ matings or of $\mathrm{Ag}(\mathrm{a}+)$ and $\mathrm{Ag}(\mathrm{a}-)$ matings could be either $A g(a+)$ or $A g(a-)$. The offspring of $\mathrm{Ag}(\mathrm{a}-)$ and $\mathrm{Ag}(\mathrm{a}-)$ matings must all be $\operatorname{Ag}(\mathrm{a}-)$.

Results in an additional 24 U. S. Negro families are presented in this report. These were casually selected from families whose sera were collected in Evans and Bulloch counties, Georgia. Studies on the following red blood cell groups were available on nearly all the family members: $A, A_{1}, B$, O, C $\left(R h^{\prime}\right), D\left(R h_{0}\right), E\left(R h^{\prime \prime}\right), c, d, r, M, N, S$, s, $\mathrm{Fy}^{\mathrm{a}}, \mathrm{Le}^{\mathrm{a}}, \mathrm{Le}^{\mathrm{b}}, \mathrm{Kp}^{\mathrm{a}}, \mathrm{Kp}^{\mathrm{b}}, \mathrm{K}, \mathrm{C}^{\mathrm{w}}, \mathrm{Lu}^{\mathrm{a}}, \mathrm{Wr}^{\mathrm{a}}, \mathrm{Vw}$, $\mathrm{M}^{\mathrm{g}}$, and Js. With these, some offspring who were not the children of the supposed parents could be detected, and they were excluded from the computations.

The frequency of the $\mathrm{Ag}(\mathrm{a}+)$ phenotype in the population studied was 55 per cent. On the assumption that mating is random, that marked selection does not occur, and that the genetic hypothesis is correct, the expected number of each kind of mating and offspring can be calculated. The expected and observed results are shown in Table VIII.

A method summarized by Smith (15) permits more complete use of the data: four types of comparison are made in each of which a correc- tion is included for family size (Table IX). For classes 3 and 4, an estimate of 0.33 was used for the $A g^{\mathbf{A}}$ gene frequency. The observed results are close to those expected and agree with the previous family studies.

Population studies. These are shown in Table II. The red blood cell groups (listed previously under Family studies) and $\mathrm{Ag}$ (a) phenotypes of 96 Georgia Negroes and 79 white inhabitants of Tangier Island, Maryland, were determined. There was no apparent association between $\mathrm{Ag}(\mathrm{a})$ and red blood cell phenotypes.

Mother-child studies. Information on the time of life when gene expression is detectable can be obtained by the study of mothers and their newborn children. Eighty-one pairs of mother and newborn sera were obtained from the U. S. Naval Medical Center, Bethesda, and the Johns Hopkins Hospital, Baltimore. The blood was drawn from the mother at term. With the exception of 16 cases where the blood was removed from the infant's heel between the second and fourth days of life, the newborns' blood was obtained from the umbilical cord at the time of delivery. Sera were also obtained from 9 infants approximately 7 weeks old, and from two of these blood was also withdrawn at age 3 months. Sera withdrawn at age 2 years were available from 12 children.

Table $\mathrm{X}$ shows the results of the mother-new-

TABLE VIII

Family studies of $\mathrm{Ag}(\boldsymbol{a})$ phenotype in U.S. Negroes

\begin{tabular}{|c|c|c|c|c|c|c|c|}
\hline \multirow[b]{2}{*}{ Mating type } & & \multicolumn{2}{|c|}{ No. of families } & \multicolumn{2}{|c|}{$\mathrm{Ag}(\mathrm{a}+)$ children } & \multicolumn{2}{|c|}{ Ag $\left(a_{-}\right)$children } \\
\hline & & Obs.* & Exp. & Obs. & Exp. & Obs. & Exp. \\
\hline \multirow[t]{2}{*}{$\begin{array}{c}\mathrm{Ag}(\mathrm{a}+) \times \mathrm{Ag}(\mathrm{a}+) \\
\mathrm{Ag}(\mathrm{a}+) \times \mathrm{Ag}(\mathrm{a}-) \\
\mathrm{Ag}(\mathrm{a}-) \times \mathrm{Ag}(\mathrm{a}-)\end{array}$} & & $\begin{array}{l}9 \\
8 \\
7\end{array}$ & $\begin{array}{r}8.3 \\
11.8 \\
4.9\end{array}$ & $\begin{array}{r}29 \\
20 \\
0\end{array}$ & $\begin{array}{c}29.4 \\
19.2 \\
0\end{array}$ & $\begin{array}{r}6 \\
12 \\
18\end{array}$ & $\begin{array}{l}5.6 \\
12.8 \\
18\end{array}$ \\
\hline & Total & 24 & 24.0 & 49 & 48.6 & 36 & 36.4 \\
\hline
\end{tabular}

*Obs. = observed, and Exp. = expected. 
TABLE IX

Observed and expected number of $A g(a-)$ chldren from various matings in $U . S$. Negro population, by method of $C$. A. B. Smith (15)

\begin{tabular}{|c|c|c|c|}
\hline Test comparison & Mating & $x^{2}$ & d.f. \\
\hline $\begin{array}{l}\text { Observed no. of } \operatorname{Ag}(\mathrm{a}-) \text { children, given no. } \\
\text { of families with } \operatorname{Ag}(\mathrm{a}-) \text { children }\end{array}$ & $\begin{array}{c}\operatorname{Ag}(a+) \\
\underset{x}{\operatorname{Ag}(a-)}\end{array}$ & .174 & 1 \\
\hline $\begin{array}{l}\text { Observed no. of } \mathrm{Ag}(\mathrm{a}-) \text { children, given no. } \\
\text { of families with } \mathrm{Ag}(\mathrm{a}-) \text { children }\end{array}$ & $\begin{array}{c}\operatorname{Ag}(a+) \\
\times \\
\operatorname{Ag}(a+)\end{array}$ & .870 & 1 \\
\hline $\begin{array}{l}\text { Observed no. of families with at least one } \\
\mathrm{Ag}(\mathrm{a}-) \text { child, given total no. of families }\end{array}$ & $\begin{array}{c}\operatorname{Ag}(a+) \\
\underset{x}{\operatorname{Ag}(a-)}\end{array}$ & .006 & 1 \\
\hline $\begin{array}{l}\text { Observed no. of families with at least one } \\
\mathrm{Ag}(\mathrm{a}-) \text { child, given total no. of families }\end{array}$ & $\begin{array}{l}\operatorname{Ag}(a+) \\
\underset{x}{A g}(a+)\end{array}$ & .099 & 1 \\
\hline & & \multicolumn{2}{|c|}{$\chi^{2}=1.149 \quad \underset{0.9>p>0.8}{\text { d.f. }}=4$} \\
\hline
\end{tabular}

born child studies arranged according to the possible combinations of mother and child phenotypes. Two major hypotheses may be considered to account for the observed results: 1) The trait is inherited according to the genetic hypothesis stated above, and the genes are expressed at birth; and 2) the trait is inherited according to the genetic hypothesis, and the genes are expressed not at birth but at varying times thereafter. Two further possibilities follow from the second hypothesis: a) The $\mathrm{Ag}(\mathrm{a})$ material is not transmitted placentally, and $b$ ) the $\operatorname{Ag}(a)$ material is transmitted placentally in some or all cases.

The data can help in deciding among these possibilities. The frequency of $\mathrm{Ag}(\mathrm{a}+)$ in the mother was 51 per cent, which was not significantly different from the frequency in the general U. S. population. On the assumptions that the genetic hypothesis is correct and that mating is random for $\mathrm{Ag}$ (a) phenotype, the combinations expected according to the first hypothesis can be calculated, and are shown in the fourth column of Table $\mathrm{X}$. There is a large deficiency of the $\mathrm{Ag}(\mathrm{a}-)$ mother, $-\mathrm{Ag}(\mathrm{a}+)$ infant combination. If hypothesis $2 \mathrm{a}$ is correct, then the presence of the $\operatorname{Ag}(\mathrm{a}+)$ material in some of the newborn children could reflect the difference in the times that the gene is expressed. The children of $\mathrm{Ag}(\mathrm{a}+)$ mothers, however, are much more frequently positive than those of $\mathrm{Ag}(\mathrm{a}-)$ mothers. In the children of the $\operatorname{Ag}(\mathrm{a}+)$ mothers, 24 of an expected 29.1 infants are $\mathrm{Ag}(\mathrm{a}+)$ at birth; in the children of the $\mathrm{Ag}(\mathrm{a}-)$ mothers, $12 \mathrm{Ag}(\mathrm{a}+)$ children would be expected, whereas only one questionable case was seen. Hence, for hypothesis $2 \mathrm{a}$ it would be necessary to assume that the children of $\operatorname{Ag}(\mathrm{a}+)$ mothers express the gene earlier than the children of $\mathrm{Ag}(\mathrm{a}-)$ mothers.

If hypothesis $2 b$ is correct, then none of the $\operatorname{Ag}(\mathrm{a}-)$ mothers should have $\operatorname{Ag}(\mathrm{a}+)$ children. Mothers who are $\mathrm{Ag}(\mathrm{a}+)$ might or might not have children with reactive serum. In one

TABLE $\mathrm{X}$

Comparison of $A g(a)$ phenotyes in mother-chld pairs

\begin{tabular}{|c|c|c|c|c|}
\hline \multirow[b]{2}{*}{ Mother* } & \multirow[b]{2}{*}{ Child } & \multirow{2}{*}{$\begin{array}{l}\text { Observed } \\
\text { no. of pairs }\end{array}$} & \multicolumn{2}{|c|}{ Expected no. of pairs } \\
\hline & & & Hypothesis 1 & Hypothesis 2 \\
\hline $\begin{array}{l}\operatorname{Ag}(\mathrm{a}-) \\
\operatorname{Ag}(\mathrm{a}-) \\
\operatorname{Ag}(\mathrm{a}+) \\
\operatorname{Ag}(\mathrm{a}+)\end{array}$ & $\begin{array}{l}\operatorname{Ag}(a-) \\
\operatorname{Ag}(a+) \\
\operatorname{Ag}(a-) \\
\operatorname{Ag}(a+)\end{array}$ & $\begin{array}{r}39 \\
1 \\
17 \\
24\end{array}$ & $\begin{array}{l}28 \\
12 \\
11.9 \\
29.1\end{array}$ & $\begin{array}{r}40 \\
0 \\
41 \\
41\end{array}$ \\
\hline & & Total 81 & 81 & 81 \\
\hline
\end{tabular}

* $A g(a+)$ frequency in mothers $=51$ per cent. 
TABLE XI

Serial studies of $A g(a)$ phenotypes in mother-child pairs

\begin{tabular}{|c|c|c|c|c|c|}
\hline \multirow[b]{2}{*}{ No. } & \multirow{2}{*}{$\begin{array}{l}\text { Mother } \\
\text { Term }\end{array}$} & \multicolumn{4}{|c|}{ Children } \\
\hline & & Birth & $\begin{array}{l}40 \text { to } 60 \\
\text { Days }\end{array}$ & 3 Months & 2 Years \\
\hline 1 & $\operatorname{Ag}(\mathrm{a}+)$ & $\mathrm{Ag}(\mathrm{a}+)$ & $\mathrm{Ag}(\mathrm{a}+)$ & & \\
\hline 2 & $\operatorname{Ag}(a-)$ & $\mathrm{Ag}(\mathrm{a}-)$ & $\operatorname{Ag}(a-)$ & & \\
\hline 3 & $\mathrm{Ag}(\mathrm{a}+)$ & $\mathrm{Ag}(\mathrm{a}+)$ & $\mathrm{Ag}(\mathrm{a}+)$ & & \\
\hline 4 & $\mathrm{Ag}(\mathrm{a}-)$ & $\mathrm{Ag}(\mathrm{a}-)$ & $\mathrm{Ag}(\mathrm{a}+)$ & & \\
\hline 5 & $\mathrm{Ag}(\mathrm{a}+)$ & $\mathrm{Ag}(\mathrm{a}+)$ & $\mathrm{Ag}(\mathrm{a}+)$ & $\operatorname{Ag}(a+)$ & \\
\hline 6 & $\mathrm{Ag}(\mathrm{a}+)$ & $\mathrm{Ag}(\mathrm{a}+)$ & $\mathrm{Ag}(\mathrm{a}+)$ & & \\
\hline 7 & $\mathrm{Ag}(\mathrm{a}+)$ & $\mathrm{Ag}(\mathrm{a}+)$ & $\mathrm{Ag}(\mathrm{a}+)$ & & \\
\hline 8 & $\mathrm{Ag}(\mathrm{a}-)$ & $\operatorname{Ag}(\mathrm{a}-)$ & $\operatorname{Ag}(a-)$ & $\operatorname{Ag}(\mathrm{a}-)$ & \\
\hline 9 & $\mathrm{Ag}(\mathrm{a}-)$ & $\mathrm{Ag}(\mathrm{a}-)$ & $\mathrm{Ag}(\mathrm{a}-)$ & & \\
\hline 10 & $\mathrm{Ag}(\mathrm{a}+)$ & $\operatorname{Ag}(\mathrm{a}-)$ & & & $\mathrm{Ag}(\mathrm{a}-)$ \\
\hline 11 & $\mathrm{Ag}(\mathrm{a}+)$ & $\mathrm{Ag}(\mathrm{a}-)$ & & & $\mathrm{Ag}(\mathrm{a}+)$ \\
\hline 12 & $\mathrm{Ag}(\mathrm{a}-)$ & $\mathrm{Ag}(\mathrm{a}-)$ & & & $\mathrm{Ag}(\mathrm{a}+)$ \\
\hline 13 & $\mathrm{Ag}(\mathrm{a}-)$ & $\mathrm{Ag}(\mathrm{a}-)$ & & & $\mathrm{Ag}(\mathrm{a}+)$ \\
\hline 14 & $\mathrm{Ag}(\mathrm{a}-)$ & $\mathrm{Ag}(\mathrm{a}-)$ & & & $\mathrm{Ag}(\mathrm{a}+)$ \\
\hline 15 & $\mathrm{Ag}(\mathrm{a}-)$ & $\mathrm{Ag}(\mathrm{a}-)$ & & & $\operatorname{Ag}(a-)$ \\
\hline 16 & $A \mathbf{g}(a-)$ & $\mathrm{Ag}(\mathrm{a}-)$ & & & $\operatorname{Ag}(a+)^{*}$ \\
\hline 17 & $\mathrm{Ag}(\mathrm{a}+)$ & $\mathrm{Ag}(\mathrm{a}+)$ & & & $\mathrm{Ag}(\mathrm{a}+)$ \\
\hline 18 & $\mathrm{Ag}(\mathrm{a}-)$ & $\mathrm{Ag}(\mathrm{a}-)$ & & & $\operatorname{Ag}(a-)$ \\
\hline 19 & $\mathrm{Ag}(\mathrm{a}-)$ & $\mathrm{Ag}(\mathrm{a}-)$ & & & $\operatorname{Ag}(\mathrm{a}+)^{*}$ \\
\hline
\end{tabular}

* Double band on Ouchterlony plate.

case, the serum of a child of an $\operatorname{Ag}(\mathrm{a}-)$ mother gave a broad, diffuse band rather than the sharp, narrow band characteristic of the usual precipitin. The presence of the $\operatorname{Ag}(\mathrm{a}+)$ material in the children of the $\operatorname{Ag}(\mathrm{a}+)$ mothers could be explained by placental transmission. This, of course, would not occur in the children of the $\mathrm{Ag}(\mathrm{a}-)$ mothers.

In order to determine when after birth the $A g^{\mathbf{A}}$ gene is expressed, blood collected at 40 to 60 days, 3 months, and 2 years after delivery was studied (Table XI). One infant's serum, which had been negative at birth, was positive at 57 days (Table XI, no. 4). Six others negative at birth were positive at 2 years (Table XI, nos. 11-14, 16, 19). If the positive material present in the cord blood was placentally transmitted, then we could expect to see some examples of the conversion of an $\operatorname{Ag}(\mathrm{a}+)$ to an $\operatorname{Ag}(\mathrm{a}-)$ phenotype in the offspring of an $\mathrm{Ag}(\mathrm{a}+)$ mother. This was not observed. There were, however, only 6 cases in which the necessary observations have been made, and in 4 the observation period was less than 60 days. With the gene frequency of $A g^{\mathrm{A}}$ as 0.33 and with random mating assumed, it can be shown that approximately 30 per cent of $\mathrm{Ag}(\mathrm{a}+)$ mothers would be expected to have $A g A g$ offspring. It is not surprising, therefore, that none was seen. Further follow-up studies are needed to see if such a conversion occurs.
Fetal Blood. Sera from five fetuses whose ages were approximately 72, 73, 84, 109, and 143 days were made available to us through the courtesy of Dr. J. Robbins. One of these gave a positive precipitin reaction with the serum of $\mathrm{C}$. de $\mathrm{B}$. This fetus was estimated to be 72 days old, but was one of the largest $(13.0 \mathrm{~cm})$ of all those examined.

Transudates. A. Synovial fluid. Sera and synovial fluid from the knees of four patients with gout was was made available to us through the courtesy of Dr. J. E. Seegmiller. Patient 1 had gout affecting primarily his metatarsal joints. He developed transient inflammation in the left but not the right knee; serum and synovial fluid from both knee joints were $\operatorname{Ag}(\mathrm{a}+)$, and there was no evidence of gout in either knee. Patients 2,3 , and 4 had gout, but with only moderate involvement of their knees. The sera and synovial fluids of Patients 2 and 3 were $\mathrm{Ag}(\mathrm{a}-)$; those of Patient 4 were $\operatorname{Ag}(\mathrm{a}-)$.

B. Cerebrospinal fluid. Both serum and cerebrospinal fluid were available, through the courtesy of Dr. P. Carbone, from ten patients with neoplastic diseases. In nearly all cases, there was no apparent involvement of the meninges. Six of the sera were classified as $\mathrm{Ag}(\mathrm{a}+)$ and 4 as $\mathrm{Ag}(\mathrm{a}-)$; all the cerebrospinal fluids were classified at $\mathrm{Ag}(\mathrm{a}-)$. The cerebrospinal fluids of the six $\mathrm{Ag}(\mathrm{a}+)$ individuals were pooled and con- 
centrated by ultrafiltration to 25 and 100 times normal. Each concentrated preparation was nonreactive.

\section{DISCUSSION}

It is reasonable to conclude tentatively that these antibodies developed in response to multiple transfusions and are comparable to those developed from repeated injections of foreign proteins into experimental animals. In this case, the foreign protein is a normal human serum component, the low-density beta-lipoprotein, of which at least two antigenically different, genetically determined forms are presumed to exist in most populations. The antigenic differences probably derive from small physico-chemical variations of the molecule. Individuals homozygous or heterozygous for the $A g^{A}$ gene have a low-density betalipoprotein that forms a precipitin with the antibody in the serum of C. de B. $A g$ homozygotes presumably have an antigenic specificity, but to date no antibody has been found that would detect the presence of this hypothesized gene product. C. de B. was presumably of type $\mathrm{Ag}(\mathrm{a}-)$ and developed an antibody as a result of multiple transfusions with $\mathrm{Ag}(\mathrm{a}+)$ lipoprotein.

The reaction between a patient's antibody and the antigen in the transfused blood might be the cause of some of the mild transfusion reactions seen in frequently transfused patients. Four of the five patients in whom antibody was detected (see Table IV) continued to receive transfusions. One of the patients, C. de B., had mild subjective symptoms and a moderate rise in temperature after most transfusions, but it appeared to be independent of the $\operatorname{Ag}(\mathrm{a})$ phenotype of the blood he received (see Figure 2). There is no information available on the long-term effect of repeated transfusions in patients who are antibody-formers. The reaction between the $\operatorname{Ag}(\mathrm{a}+)$ protein and C. de B. antibody does not fix complement (7), nor does it give a positive passive cutaneous anaphylaxis test. It is posible, however, that recurrent precipitin reactions may occur in vivo and have long-term, chronic pathological consequences, particularly in small blood vessels.

In three of the five antibody-formers, C. de B., P. C., and Br., the antibodies appeared to be qualitatively similar. $\mathrm{P}$. C. and $\mathrm{Br}$. were both $\mathrm{Ag}(\mathrm{a}-)$, and none of these three sera formed precipitin lines with each other. M. and Ba. were both $\mathrm{Ag}(\mathrm{a}+)$ and formed precipitin lines with the antigen present in C. de B.'s serum. They appear to determine quite different precipitin systems, and will be described in detail elsewhere.

It is not known why some of the transfused patients developed an antibody and others did not. Those who did received a minimum of approximately 40 transfusions, but a large number of transfusions is not the only requirement for antibody formation. Fifteen of the frequently transfused patients had received more than 100 transfusions, but antibody was detected in only two of these. Of the 15 , three had received 300 or more transfusions, but no precipitin was found in any of these. Three of the antibody-formers had thalassemia. Here the antibody production may result from the large number of transfusions these patients receive, or it may reflect some inherent characteristic of the disease.

The Ouchterlony method is a relatively crude means for detecting antibody ; it is likely that more sensitive techniques would reveal a larger number of antibody-formers, and studies using such methods are in progress.

The presence of a precipitin band with a different appearance from the usual concave one, and the occasional finding of two separate bands, suggest that the serum of $\mathrm{C}$. de $\mathrm{B}$. can react with more than one antigenic site.

These studies are in general consistent with the original genetic hypothesis. We conclude that the genetic mechanism proposed explains the major variations of this trait, although other genetic and environmental factors may have a bearing on the formation of the specific lipoprotein. This trait is polymorphic in most of the populations studied, and the gene frequency varies widely.

The mother-child studies are consistent with the explanation that the antigen is not generally produced at birth but that synthesis begins at a variable time thereafter. This effect is analogous to that with the serum haptoglobins, where a large percentage of children have no haptoglobins until after the third month of life (16). It is possible that the $\operatorname{Ag}(\mathrm{a}+)$ material crosses the placenta in sufficient quantity to be detected in some offspring of $\mathrm{Ag}(\mathrm{a}+)$ mothers.

The $\mathrm{Ag}(\mathrm{a}+)$ material is present in the synovial fluid of $\operatorname{Ag}(\mathrm{a}+)$ individuals, implying that 
the specific lipoprotein either is transmitted across the synovial membrane or is produced in the joint. The $\operatorname{Ag}(\mathrm{a}+)$ material was not detected in the spinal fluid.

\section{SUMMARY}

1. Further studies on the $\operatorname{Ag}(\mathrm{a})$ human serum polymorphism, which involves low-density betalipoprotein components, are presented. Population, family, and twin studies agree with the hypothesis that the presence of this component, which is identified by a precipitation reaction with the serum of a patient who had received numerous transfusions, is determined by an autosomal, dominantly-transmitted gene designated $A g^{A}$.

2. Examination of the paired sera of mothers and newborn children leads to the conclusion that the $\mathrm{Ag}(\mathrm{a})$ phenotype may not be expressed at birth. Mothers may transmit the lipoprotein under discussion across the placenta in some cases, rendering the newborn a phenocopy. From the evidence at hand, the $\operatorname{Ag}(\mathrm{a}+)$ phenotype can be expressed as early as 57 days after birth.

3. In one of the antibody-forming patients, C. de B., the slight temperature rise in response to transfusion was independent of the $\mathrm{Ag}$ (a) phenotype of the transfused blood. After the discovery of antibody, four of the five antibody-formers continued to receive transfusions with no apparent severe reaction.

4. Study of other transfused individuals has detected four subjects who form precipitins with normal sera. All of these patients received approximately 40 or more transfusions.

\section{ACKNOWLEDGMENTS}

We are indebted to the following for their kind assistance in collecting blood from transfused patients: Drs. Marion Erlandson, A. J. Cooper, H. C. Goodman, R. H. Aster, D. E. Gentile, R. Osborne, P. Carbone, J. E. Ultman, P. Calabresi, and S. V. Kevy. We are particularly grateful to Drs. C. H. Smith and Marion Erlandson of The New York Hospital for permitting us to obtain several specimens from their patients and providing clinical information on some of these. We appreciate the kind assistance of Dr. H. Pierson of the U. S. Naval Hospital, Bethesda, and of Drs. J. L. Sever and V. E. Anderson of the Perinatal Research Branch, National Institute of Neurological Diseases and Blindness, for providing the mother-child sera. Dr. J. R. McDonough was instrumental in obtaining the sera from Claxton and Bulloch counties, Ga. Sera from the N.I.H. employees were obtained through the courtesy of Dr. J. M. Lynch of the Employees' Health Service.

\section{REFERENCES}

1. Blumberg, B. S. Inherited susceptibility to disease and its relation to environment. Arch. environm. Hith. 1961, 3, 612.

2. Clausen, J., and Heremans, J. An immunologic and chemical study of the similarities between mouse and human serum proteins. J. Immunol. 1960, 84, 128.

3. Hirschfeld, J. Shape of the precipitate in immunoelectrophoresis. Nature 1960, 185, 164.

4. Oudin, J. L'allotypie de certains antigènes protéidiques du serum. C. R. Acad. Sci. (Paris) 1956, 242, 2606.

5. Dray, S., and Young, G. O. Two antigenically different $\boldsymbol{\gamma}$-globulins in domestic rabbits revealed by isoprecipitins. Science 1959, 129, 1023.

6. Dubiski, S., Dudziak, Z., Skaiba, D. Serum groups in rabbits. Immunology 1959, $2,85$.

7. Allison, A. C., and Blumberg, B. S. An isoprecipitation reaction distinguishing human-serum protein types. Lancet 1961, 1, 634.

8. Blumberg, B. S., Dray, S., and Robinson, J. C. Antigen polymorphism of a low-density beta-lipoprotein. An allotypy in human serum. Nature 1962, 194, 656.

9. Blumberg, B. S., and Allison, A. C. Studies on the isoprecipitin determined human serum polymorphins to "new" phenotypes. Proceedings of the Second International Conference of Human Genetics, Rome, September, 1961.

10. Blumberg, B. S., Allison, A. C., and Garry, Barbara. The haptoglobins and haemoglobins of Alaskan Eskimos and Indians. Ann. hum. Genet. 1959, 23, 349.

11. Blumberg, B. S., and Gartler, S. M. The urinary excretion of $\beta$-aminoisobtuyric acid in Pacific populations. Hum. Biol. 1961, 33, 355.

12. Blumberg, B. S., and Gentile, Z. Haptoglobins and transferrins of two tropical populations. Nature 1961, 189, 897.

13. McDonough, J. R., Hames, C. G., Greenberg, B. G., Griffin, L. H., Jr., and Edwards, A. J., Jr. Observations on serum cholesterol levels in the twin population of Evans County, Georgia. Circulation 1962. In press.

14. Smith, M., and Penrose, L. S. Monozygotic and dizygotic twin diagnoses. Ann. hum. Genet. 1955, 19, 273.

15. Smith, C. A. B. A test for segragation ratios in family data. Ann. hum. Genet. 1956, 20, 257.

16. Galatius-Jensen, F. On the genetics of the haptoglobins. Acta genet. (Basel) 1958, 8, 232. 